\title{
The Development of Social Capital between Operational Academics Delivering Transnational Collaborative Programme Partnerships
}

\begin{abstract}
The bonds that unite partner institutions in the delivery of shared transnational collaborative programmes are critical in the effective management of these education partnerships. A crucial component in this unification is social capital, where partners connect and develop networks, lubricated by trust, which facilitates cooperation and commitment to the venture, producing purposive and beneficial outputs. This paper explores this phenomenon by investigating the way social capital manifests between operational colleagues tasked in the delivery of collaborative joint-degree programme partnerships. Initially, the paper explores the relationship between 'partnership' and 'social capital'. It then analyses three sociological perspectives of social capital, the rational, critical and democratic strains, before examining them in relation to empirical data collected from three collaborative programme partnerships. The paper concludes there is evidence of all three strains, but advocates partner institutions observe four recommendations, so to encourage the manifestation of the beneficial critical and democratic strains.
\end{abstract}

Key words: Transnational collaborative programmes, partnerships, social capital, operational academic members, practice.

\section{Introduction}

According to Knight (2004), internationalisation has created new opportunities in the global higher education (HE) market, with higher education institutions (HEIs) seeking to take advantage of such opportunities, by developing their conceptual understandings of internationalisation as well as their strategic responses. This growing interest has translated into the active development of strategies, policies, programmes, and infrastructures that highlight the importance of internationalisation. To compete globally, many HEIs seek to promote their HE services to overseas markets. Strategies may include the development of branch campuses (Shams \& Huisman, 2016), academic member and student exchanges, or transnational higher education partnerships. Although these types of overseas ventures can vary in complexity, affected by changing political, social, and economic developments, they fundamentally require two or more educational institutions to develop relationships inspired by a shared vision and language, underpinned by trust and cooperation.

This paper aims to contribute to the field of transnational partnership management, by specifically investigating partnering institutions and their operational relationships. To ensure existing and future international partnerships operate successfully, it is vital that stakeholders involved understand how to develop and optimise their relationships (Taylor, 2016). In this instance, social capital is deemed to be the critical ingredient that forms and maintains successful partnerships (Dhillon, 2013; Eddy, 2010). The research presented here, aims to investigate how social capital manifests between operational academic staff members who operate and deliver transnational collaborative programmes on a daily basis, and seeks to explore ways it can be developed to strengthen partner relations over time.

However, measuring a concept such as social capital is fraught with difficultly (Paldam, 2000), with multiple sociologists postulating social capital differently. This paper therefore, starts by exploring the connection between 'partnership' and 'social capital' discourse. It is argued that 
social capital is fundamental to the sustainability and productivity of any partnership (Dhillon, 2013; Eddy, 2010), since it refers to attributes such as trust, cooperation, respect, and support between colleagues. It is therefore vital that collaborating partners understand the nature of social capital and the way operational interactions can affect its production. Social capital is explored herein through engagement with the work of three seminal sociologists: Pierre Bourdieu, James S. Coleman and Robert D. Putnam. All three perspectives are analysed, then subsequently applied to empirical data collected from a study of three TNE collaborative joint -degree programme partnerships; with each partnership analysed to discover how social capital manifests at the operational level.

\section{The research context: introducing transnational collaborative programme partnerships}

First, it is appropriate to explain the context surrounding the empirical research presented in this paper. Transnational higher education (TNE) provides the research context; described by UNESCO and the Council of Europe Section 1 (2002) as "all types of higher education study programmes...in which learners are located in a country different from the one where the awarding institution is based". Whilst transnational partnership configurations vary, depending on providers, programmes, disciplines, stakeholders and national agendas, the growing importance of transnational education as a method by which to grow international links and reputations, as well as the financial benefit afford by these ventures, cannot be underestimated (BIS, 2014). It is estimated that as trade in HE develops, so will transnational education, therefore increasing the likelihood that programme and institutional mobility will eclipse student mobility in future years.

Since TNE encompasses multiple typologies such as branch campuses, distance learning, and collaborative provision (BIS, 2014), it is impossible to analyse all forms of TNE and social capital in this paper. Collaborative provision (CP) was therefore identified and utilised in this study to analyse partner operational relationships. The UK's QAA (2010, p.2) define CP as "all forms of TNE provision, such as 'validation, franchise, articulation, joint, dual degrees...based learning"” that require partners to work together to deliver the educational service. In the context of this study, the research sample consisted of academic staff members who were operating a collaborative jointdegree programme partnership. Knight (2008) defines a joint-degree as a programme whereby one award is granted upon completion of the collaborative programme requirements established by the partner institutions. Furthermore, she stipulates that the generic term use to describe international joint, double of other combined degrees and their management is an 'international collaborative programme' (2008, p.4).

\section{Developing a transnational partnership: key features and requirements}

So, what is a partnership and how do they develop? Organisational and business research which explores 'partnership' often analyses and evaluates them based on their construction, purpose, and value. Partnerships are often used as a way of gaining an advantage in the marketplace, whether 
this affords an organisation access to new technologies, revenue streams, the ability to provide a wider range of products or services, or access to new knowledge, partnerships serve a purpose within and between organisations (Mohr \& Spekman, 1994). Therefore, partnerships are often analysed in relation to the contribution they make to the maintenance and survival of organisations. Transnational partnership discourse is no different, with the initiation phase of these partnerships and the motivations, such as revenue generation, programme expansion, knowledge acquisition, and increased student numbers often analysed in detail (Helms, 2015). Although this strategically focused research is of critical importance, academics such as Zhuang (2009) provide further insights into the initiation phase of a transnational partnership by exploring the development of social capital between senior executives, positing it as being fundamental in the strengthening of partner relations over time.

However, whilst an exploration of the initiation phase of transnational partnerships is important in providing the framework for partnership engagement, there is arguably a need to counter-balance this with research with an exploration of how operational interactions between partners effects the direction, effectiveness and efficiency of transnational partnerships. This is of grave importance, since engagements between operational colleagues often set the tone and conditions in which overseas programmes operate. The operational phase is where the educational service is generated, maintained and developed by academic members, who use their academic skills and competencies to develop overseas relationships, improve educational standards and enhance student experiences.

Nonetheless, it would be wrong to suggest that the operational phase of transnational partnerships have not previously been examined. On the contrary, bodies of work exist that investigate the operational phase of various types of TNE, from studies of online and branch campus operations, to collaborative provisions. Yet, these studies often use these international contexts to focus on issues such as quality assurance, pedagogy (Hoare, 2013), or academic professional development (Smith, 2012). Whilst these forms of research enable us to understand the more policy, practical and practice-based developments occurring in various forms of TNE, there is a need to expand research beyond these dimensions.

The operational phase of a transnational partnership can also be explored to gain insights into the way relationships between overseas operational academic members develop, and the implications this has on partnership progression. Research conducted by Heffernan and Poole (2004, 2005), provide insights into the key factors required to make international partnerships a success. They cite "effective communication, trust and commitment" (2005, p. 237) as being critical in the development of partner relations. Although not specifically focused on TNE, their work identifies the importance of social capital between strategic executives, and champions the salience of social capital in unifying international educational partners. A more recent study by Heffernan, Wilkins and Mohsin Butt (2018) explores the importance of institutional reputation, 
trust and student -university identification in international partnerships. They argue the more a partner institution can evidence their competency, credibility and ethical behaviour, the greater the level of student trust and university identification. Consequently, they suggest that managers must seek to ensure 'that their institution delivers programmes and services efficiently and effectively' (2018, p. 237). To ensure this occurs managers need to focus on developing relationships between their institutions that support communication, cooperation and reciprocation. Other studies on international educational partnerships also identify attributes, which can be likened to social capital, such as enhanced communication (Dobos, 2011), openness, knowledge transfer (Shore \& Groen, 2009) and mutual learning (Helms, 2015), as being critical to a partnership's success.

Further work conducted by Keay, May and O’Mahony (2014) suggests that successful transnational delivery requires an understanding of the quality of relations that reside "between partners for the enhancement of practice" (2014, p. 252). By considering partnership as a fusion of “joint enterprise, mutual engagement and shared repertoire" (2014, p. 257), they suggest enhancements can be made to transnational teaching and learning by analysing and developing these attributes. Yet, no empirical work has been conducted that explores how these features manifest between academic members operating transnational collaborative programme partnerships, or how they affect operational processes and partner relations over time.

Essentially, when academic members engage in operational interactions, they connect, developing mutual interests and common goals. Shared meaning of language therefore occurs, resulting in a combined action or outcome greater in total effect than the sum of individual actions (Gray, 1985). Building social capital stimulates these shared understandings, which moves the partnership beyond individual partners into a collective enterprise (Eddy, 2010). Partnership is thus defined by its unifying and bonding developments (Billett, Ovens, Clemans, \& Seddon, 2007) whereby emotions, practical action and reason are integral to activities influencing the way in which relationships evolve. Once these networks form, trust becomes a central component, which acts as a lubricant, facilitating further interactions between members (Putnam, 2000). Operational social capital therefore represents a critical component in the forming and maintaining of longterm, successful relationships and thus partnerships (Eddy, 2010). Consequently, it seems logical to explore social capital theory in greater detail, before considering how an understanding of these theories can help improve operational relations and practices.

\section{Analysing social capital: three sociological perspectives}

Whilst numerous academics such as Burt (1997) and Lin (2001) have contributed to the conceptual developed of social capital, this paper utilises the work of three of the most influential Western social capital theorists: Bourdieu (1980, 2006), Coleman $(1994,1998)$ and Putnam $(1993,1996$, 2000). Their work can be summarised under three headings: the rational, critical, and democratic strains of social capital (Adams, 2011). The rationale for exploring these three perspectives is to 
draw out the substantive ideas of each sociologist, so to apply these in an analysis of three TNE partnerships. It must be noted at this point, that the sample utilised in this research study are all Western, with no participant originating from an Eastern background. This is to alleviate any concerns the reader may have about the suitability of applying Western sociological perspectives to Eastern social contexts.

\section{- The critical view of social capital}

The critical view suggests social capital represents the 'sum of resources', both physical and mental that "accrue to an individual or group, by virtue of possessing a durable network of more or less institutionalised relationships of mutual acquaintance and recognition" (Bourdieu \& Wacquant, 1992, p.119). To Bourdieu (1980) social capital was therefore a form of currency, enabling individuals to obtain opportunities and advantages in society. However, these resources, embedded in a network of relationships, are dependent on an individual's position and the number of connections they have, and the value contained in these ties. A person's rank thus influences the generation and attainment of social capital, with social capital often characterised by its function in the reproduction of inequality across the generations (Portes, 2000).

Additionally, for social capital to maintain its value, Bourdieu (1980) argues connections require work. The reproduction of social capital presupposes an unceasing effort of sociability, a continuous series of exchanges in which recognition is endlessly affirmed and reaffirmed. Moreover, solidarity within networks is only possible because membership gives rise to profits, both material and symbolic (Field, 2008). Agents must develop investment strategies that can transform contingent relationships into social relationships that are directly useable in the short or long term. To be effective over the long-term, Bourdieu argues relationships must have "durable obligations subjectively felt" (1980, p. 2), whereby individuals feel obligated to one another through the generation of continuous benefits. Nonetheless, Bourdieu's (2006) conceptualisation suggests networked members need to be continuously aware of the benefits of their relationship. Should individuals lose sight of the benefits of their interactions, either through misinterpretation or miscommunication, relational problems could arise.

\section{- $\quad$ The rational view of social capital}

The rational view utilises the intellectual framework of rational choice theory to develop the concept of social capital (Coleman, 1994). To Coleman, social capital is defined by its function and is anything that facilitates individual or collective action, generated by social structures. Rational choice theory argues that human behaviour results from individuals pursuing their own interests, and in Coleman's conception, social capital is a neutral resource that facilitates any manner of actions, but whether society is better off as a result depends entirely on the individual uses to which it is put. Social interaction is therefore, viewed as a form of exchange (Field, 2008), with Coleman (1994) arguing that society is merely an aggregation of social systems, consisting of individual 
behaviours. To understand social order, system levels must be deconstructed, shifting the focus to individual actions and preferences. Rational choice, hence, "assumes a highly individualistic model of human behaviour"' (Field, 2008, p. 24), whereby individuals operate to suit their own interests regardless of the fate of others.

This theory predicts individuals will follow their own best interests, even when cooperating may yield a greater return in the long term. Although rational choice theorists find it hard to evidence how cooperation is consistent with notions of individualism, Coleman (1994) utilises social capital as a means of explaining why individuals choose to cooperate even when individual interests are best served through competition. Social capital consequently, bridges the gap between the individual and the collective, with Coleman (1994) describing social capital as 'a capital asset for the individual' (1994, p. 334). Burt (1997) mirrors this perspective by suggesting social capital represents a form of competitive advantage, which can assist individuals in the pursuit of individual objectives.

According to Coleman (1988), social capital can be considered a resource which is available to an agent through their social relationships. Furthermore, agents may exercise control over resources in which they have an interest, but these resources are also controlled and directed by the actions of other individuals and their outcomes (Coleman, 1994). Agents, therefore, interact and engage in exchanges, constantly transferring resources so that their individual gains are maximised. These social relationships serve important functions in facilitating the actions of individual actors, and form the basis of social capital.

Similarly, to the critical view, terms such as resourcing, social structures and benefit are commonplace. However, the rational strain expands our understanding of social capital by introducing ideas of individualism, and perceived personal gains. Whether an individual perceives social capital as an investment however, depends on the return it yields for that individual after undertaking a specific action. Therefore, social capital represents an investment in social relations with an expected return (Lin, 2001).

\section{- The democratic view of social capital}

The final strain requiring analysis is the democratic view championed by Putnam, who initially defined social capital as "features of social organisations, such as trust, norms and networks that can improve the efficiency of society by facilitating coordinated action" (1993, p. 167). During the mid1990s, Putnam further explored the concept defining social capital as "features of social life networks, norms and trust - that enable participants to act together more effectively to pursue shared objectives" (Putnam, 1996, p. 56). Although the definition changed slightly, the focus shifted to participants as the beneficiaries of social capital. The idea of social networks connecting individuals had value. It was in these connections that norms of reciprocity and trust developed, with two distinctions being made in the type of social capital that exists (Putnam, 2000, p. 22): 
1. Bridging social capital: This tends to refer to networks, which link external assets as well as providing platforms for the diffusion of information. Often referred to as weak ties (Granovetter, 1983), it is these links to distant acquaintances, who operate in different circles, that generate broader identities and reciprocity. These can assist in helping agents in gathering information and opportunities.

2. Bonding social capital: This reinforces exclusive identities and maintains homogeneity. It is ideal for fortifying specific reciprocity and mobilising solidarity: Putnam (2000) defines it as "a kind of sociological superglue" (p. 23).

Putnam (1993) contends that social capital and its development is of fundamental importance to both individuals and society. From an individual perspective, he argues those with higher levels of social capital are happier. From a societal perspective, strong social networks tend to foster mutual obligations between people, whereby individuals feel obliged to assist and behave morally towards those with whom they are involved (Putnam, 2000). Key to Putnam's work is the concept of reciprocation and its effect on the building of trust. Reciprocation encourages cooperative behaviour and aids in group learning, thereby facilitating the development of new forms of engagement and value creation. It, therefore, seems that the type of connection between individuals and reciprocation are critical in generating key partnership traits such as trust, cooperation, and value.

\section{Summarising the key facets of social capital}

The table herein, provides the reader with a summary of the key attributes extracted from each of the sociological perspectives presented above:

\begin{tabular}{|l|}
\hline The critical view \\
\hline $\begin{array}{l}\text { Social hierarchy, resources (physical and mental), institutionalised relationships, networks, solidarity, } \\
\text { durable obligations, invested effort, benefits, reproduction. }\end{array}$ \\
\hline The rational view \\
\hline $\begin{array}{l}\text { Resourcing, functional, social structure (network), individualism, individual actions and behaviours, } \\
\text { individual objectives, investment, individual gains. }\end{array}$ \\
\hline The democratic view \\
\hline $\begin{array}{l}\text { Coordinated action, networks, trust, connectivity, reciprocation, cooperation, shared objectives, shared } \\
\text { values, obligations, bonding and bridging. }\end{array}$ \\
\hline
\end{tabular}

Table 1: Summary of key facets

Based upon the aforementioned analysis of transnational partnership literature and social capital theory, it seems that the critical and democratic strains resonate more with the narrative of effective and productive partnerships (Eddy, 2010; Gray, 1985). It is these strains that harmonise with partnership discourse that suggest constructive and rewarding partnerships are founded upon 
beneficial, connected, trusting, shared and reciprocal relationships (Dhillon, 2013). The next section uses the facets expressed in table 1 to examine social capital development in operational contexts.

\section{Empirical research: introducing three transnational partnerships}

Depending on the phenomenon under study, the nature of the research questions, and considering the implicit need for quality in any research process, a holistic, multiple-case design comprising of three Chinese-British transnational partnerships was utilised for the purposes of this research. To ensure research credibility, a reasonable homogeneous sample was sought. Due to the differences that exist in transnational modes of delivery, it was important to ensure a level of consistency in terms of the provision types and delivery methods. Homogeneous sampling therefore assisted in the generation of simplified and focused research. Although each of the partnerships clearly contained a level of variance, it was important to consider how internal and external validity, or credibility, dependability, and transferability would be maintained (Lincoln \& Guba, 1989). By having the partnerships classified in the same way by HESA (Higher Education Statistics Agency) and by having them located at one host institution, it was possible to monitor the validity and quality of the research.

All three of these partnerships return data to the Higher Education Statistics Agency (HESA) under the classification of collaborative provision, as joint-degree provisions. Access to the research sample was possible through the researcher's TNE network and comprised of 'operational academic staff members' (such as programme leaders, course leaders, module leaders or local tutors) who were involved in the operational (teaching and learning) delivery of their programme. All UK staff members assisted their China-based colleagues by providing teaching via a 'fly-in-fly-out' mode of delivery, usually comprising of block teaching weeks.

All UK and China-based academic members were from Western countries, thereby sharing similar traditions and values. Native Chinese academics worked in the partnerships but only as administrators or senior executives (who were not part of the sample). Only a small number of UK and China-based staff members operate these partnerships on behalf of their institutions. Therefore, whilst participant numbers seem low, the participation rates as a percentage were $100 \%$ of members from partnership A, 50\% for partnership B and 75\% for partnership C. The configuration of each case, participant pseudonyms and nationalities are documented in table 2. 


\begin{tabular}{|c|c|c|c|c|c|c|}
\hline $\begin{array}{l}\text { Chinese } \\
\text { Institution }\end{array}$ & $\begin{array}{l}\text { UK } \\
\text { Institution }\end{array}$ & Partnership & Discipline & $\begin{array}{l}\text { Partnership } \\
\text { Duration }\end{array}$ & China-based Members & UK Members \\
\hline \multirow[t]{3}{*}{$\begin{array}{l}\text { X } \\
\text { (Single } \\
\text { institution in } \\
\text { China) }\end{array}$} & A & (X and) $\mathrm{A}$ & $\begin{array}{l}\text { Business } \\
\text { (Management) }\end{array}$ & 6 years & $\begin{array}{l}\text { China-based A } \\
1 \text { course leader } \\
\text { Tom (American) } \\
2 \text { local academics } \\
\text { Hannah (French) } \\
\text { Eliza (Swedish) }\end{array}$ & $\begin{array}{l}\text { UKA } \\
1 \text { course leader } \\
\text { Ann (British) } \\
2 \text { module leaders } \\
\text { Louise (British) } \\
\text { Keith (British) }\end{array}$ \\
\hline & $\mathrm{B}$ & (X and) $\mathrm{B}$ & STEM & 8 years & $\begin{array}{l}\text { China-based B } \\
1 \text { course leader } \\
\text { Gary (British) } \\
1 \text { local academic } \\
\text { Jun (British) }\end{array}$ & $\begin{array}{l}\text { UKB } \\
2 \text { module leaders } \\
\text { Steve (British) } \\
\text { Kevin (Italian) }\end{array}$ \\
\hline & $\mathrm{C}$ & (X and) $\mathrm{C}$ & $\begin{array}{l}\text { Business } \\
\text { (Finance) }\end{array}$ & 6 years & $\begin{array}{l}\text { China-based C } \\
1 \text { course leader } \\
\text { David (Canadian) } \\
2 \text { local academics } \\
\text { Sally (British) } \\
\text { Charles (British) } \\
\end{array}$ & $\begin{array}{l}\text { UKC } \\
1 \text { course leader } \\
\text { Lidia (British) } \\
2 \text { module leaders } \\
\text { Rob (British) } \\
\text { Claire (British) }\end{array}$ \\
\hline
\end{tabular}

Table 2: Case configuration

All participants were sent a project outline and invited to attend an individual, semistructured interview, by the researcher regarding their operational experiences, responsibilities and challenges. Each interview lasted approximately between 80- 90 minutes, was recorded and subsequently transcribed, with permission granted by all participants. Each transcript was assessed thematically by hand, with the key attributes presented in table 1 providing the analytical focus.

Initially, the transcripts were coded based on descriptive, low inference codes, before inferential pattern codes were used to pull together material into smaller and more meaningful units. Furthermore, the researcher retained a high level of reflexivity during the research process, whereby the reflective remark sheets of Miles and Huberman (1994, p.66) were used to capture any initial thoughts and observations during data collection. The frequency of the codes allowed the researcher to observe and evaluate which of the three strains of social capital were apparent in each partnership and the effect they were having on operational relationships and developments.

\section{Transnational operational relationships: evaluating the critical view of social capital}

As Bourdieu (2006) acknowledged, a key motivation for engaging with one another in a networked relationship, is the benefit an individual or group receives, whether that be tangible or intangible in nature. In a TNE (institutionalised) relationship, this suggests both strategic and operational agents at both partner institutions must clearly understand what they are working towards (purpose), and the continuous benefits that come from operating in a transnational networked relationship. It is this understanding that keeps agents obligated to one another.

Kevin commented on how his partnership was beneficial to his overseas students, since they "did not have to travel for a UK education", yet every other participant interviewed perceived "money" or "revenue" to be the main reason for their partnership. Although certain UKA and UKC participants commented on the occasional benefit afforded to them in terms of being able to "travel for teaching" (Keith) and "exposure to the Chinese culture" (Claire), it became apparent that all 
participants felt senior leaders (in the UK and China) had failed to establish and communicate the purpose, benefits and ambition of their partnership;

I was told we were getting ready to develop the final year for franchise, then I heard that was not the case, so I did not understand what was going on, I never got a clear answer (Eliza, ChinaA).

Steve commented on how this lack of clarity effected his ability to perform and develop their partnership;

I'm not even a hundred percent on the partnership structure, that's how bad it is. I'm embarrassed to say I don't even know how it links up... yet we should be empowering everybody and really driving everyone towards an improved partnership position. This is not the case (Steve, UKB).

According to Bourdieu (2006), agents, in this case operational academic members, must understand the benefits of working together to keep them obligated. Consequently, he may suggest that an academic member, who fails to understand the purpose and benefit of their work, both personally and/or institutionally, may become disengaged, thereby reducing the generation of material and symbolic profits. Although every participant understood the commercial rationale underpinning their partnership, in partnership A, C and UKB, it became apparent that a lack of strategic clarity affected operational team motivation and morale. Words like "frustration", "apathy" and "confusion" were frequently repeated. Many could not see the benefit of their operational interactions, what it counted for, and its overall benefit to the transnational partnership, thereby damaging the obligations subjectively felt between individuals;

[I]t's just a bit of a factory, and we are just pushing sausage meat through a mill and sausages come out the other end. You get that feeling sometimes, it's certainly not this wonderful relationship where everyone's contributing amazing ideas (Sally, ChinaC).

Transnational collaborative programme partnerships represent networks of academic members who operate within a deliberate construction of sociability. As Bourdieu and Wacquant (1992) suggest, between these agents lie both physical and mental resources that only they can access, depending on their rank and position. All participants referred, at some point, to the physical resources required to operate their provisions, such as the built environment, "offices", "laboratories", and "classrooms" (Ann, Kevin) and "books", "computers", and "audio-visual equipment" (Steve, Rob). However, it was Tom, Kevin, and Gary, who made specific reference to tangible resources and the challenges they faced getting senior management to invest in materials to service their programmes. Kevin remarked how he felt his overseas colleagues were "disadvantaged by a lack of investment in teaching materials". He described trying to access 
resources, but then resorting to reconfiguring his "approach to teaching" to "compensate for their [UK based senior leaders] lack of teaching provision". Notwithstanding his need to "reassure" his overseas colleague that his Chinese students would "not be disadvantaged", adding stress to their relationship.

Mental resources were described by participants as "ideas", "information", "knowledge", and "support", with Tom, David and Steve remarking on how these resources were hard to access or accrue, depending on the position staff hold within the partnership structure. Hannah and Eliza described how they perceived their course leader to purposively limit their access to intangible resources. Eliza reported how she felt Tom "blocked access to important resources" creating "segregation within the team", and blamed this on Tom's personal motivation around a "need for control". In this instance, it seemed that higher ranked staff who find themselves in a position of power, may have access to certain resources that they are able to accrue, access and share according to their inclination.

Similar feelings were reported by UKA, UKB and UKC whereby information requests concerning "projected student numbers" (Ann), "access to teaching materials" (Claire) or "assistance in the marking of student assignments" (Keith), could be withheld or dismissed by colleagues for no apparent reason. These academic members all reported feelings of "frustration" (Steve) and "suspicion" (Keith) due to obstructions in the flow of intangible resources that give their work direction and meaning. Hence it seems hierarchy and position can influence how operational academic members feel about their working environment. Moreover, it seems that rank can influence the generation and attainment of social capital, whereby agents are either limited or empowered in their ability to make beneficial improvements to operational setting (Portes, 2000).

In relation to Bourdieu's (2006) understanding of social capital, those who cannot generate benefits for the other, cannot feel obligated to one another. He may therefore suggest that to keep operational academic members obligated to one another, and benefits flowing, clarity of purpose and resource access and allocation, needs to be addressed to keep the whole operational network functioning.

\section{Transnational operational relationships: evaluating the rational view of social capital}

By postulating social capital within a rational choice intellectual framework and within an operational transnational context, it would seem cooperation only occurs because it assists in fulfilling personal objectives; whereby individuals who seek to advance themselves use their relationships to access resources embedded in the partnership network to gain individual returns, or preserve gains. This mirrors the notion of human capital in its assumption that investments made by the individual will yield a return for the individual (Becker, 1964). However, when applying this conceptual approach to social capital in transnational partnerships, more analysis is required. 
Since collaborative provision can be conceived as a restricted form of exchange (LéviStrauss, 1969), academic members who operate in these social structures do not necessarily participate through choice, but through the terms of their employment. Although certain HEIs may allow staff to choose the extent to which they engage in transnational activity, all academic members in partnerships A, B and C found themselves recruited to their partnership when they either joined their HEI, or when their HEI decided to pursue a new internationalisation strategy. Clearly, the notion of a closed or restricted group is advantageous as it can maintain trust, norms and authority. However, although these can be described as solidifying forces that assist in the reproduction of group solidarity, transnational partnerships are not closed through the choice of the actors, but by formal or informal agreements established by senior leaders, which create membership boundaries. So, the choice to 'close' the group is not at the discretion of the academic members. Furthermore, who is let into the group is not under their control, arguably challenging group solidarity.

Lin (2001) contends that closure of a group is impractical and that access to other resources that lie outside of the group are equally important. However, in the context of transnational collaborative programme partnerships, the extent to which operational academic members can access resources, which lie external to their partnership, to increase their social capital, is questionable. Apart from bridging with other HEIs and stakeholders who have an interest in the provision, any attempt at obtaining resources not possessed by either partner institution, or seeking external engagement, could be deemed as breaching the terms and conditions of agreements. In addition, bridging could also be viewed as the sharing of resources in return for a favour, which could increase reputational risk or competition, thereby possibly representing more harm than good.

The rational view believes that social capital does not tend to distribute evenly, with individual access to resources often influencing its development (Adams, 2011). Applying this to transnational operational contexts, it suggests operational academic members are likely to develop social capital in different ways, depending on their ability to access and mobilise resources in the pursuit of personal gain. There was evidence of the rational strain in partnership A, where Hannah and Eliza interpreted Tom's control of resources as being his way of "assuring his position within the operational function" (Eliza). Therefore, it seemed Tom was perceived as using his position to pursue personal advantage. This control was also observed by Ann who considered this type of individualism to be "damaging to partner relations and overall programme performance".

The same individualism was observed in UKB, UKC and China-based C, with some members suggesting that individual preservation was the only way to survive when working on an overseas programme. There was a sense of anger when Kevin spoke about the lack of support they received in dealing with their overseas workloads, describing how "there is no managerial support! So I do my own thing". Charles made a similar comment "Support? you look after number one", 
whilst Rob observed how he felt China-based "colleagues often look for ways in which to benefit themselves over that of the programme". These findings suggest that academic members can be drawn towards the pursuit of individual objectives if institutional processes do not support and guide them in their operational endeavours.

\section{Transnational operational relationships: evaluating the democratic view of social capital}

How collaborative provision is constructed and marketed to staff members plays a critical part in the type of connections that form between awarding and host institution members of staff. Bonding social capital (Putnam, 2000) arguably represents the type of capital one would expect to observe between staff members servicing a provision within the same institution. These teams, for example China-based or UK, would have similar identities and objectives arguably making the initiative being undertaken easier to manage, one would expect.

Findings from China-based B, UKC and UKA evidence the presence of high levels of intra-institutional bonded social capital, with these groups all describing their internal relationships positively. Comments concerning "high levels of empathy and trust" (Jun), "excellent communication" (Lidia) and "respect for team members" (Louise) reinforce group identity and homogeneity. In contrast, China-based A, C and UKB evidence how solidarity is not necessarily founded on positive states, but comes from a sense of "frustration" (Hannah), or shared "ignorance of the bigger picture" (Steve) or suspicion of partners (Tom, Eliza, Charles, Sally). These intrateams thus seem to predominately bond and gain identity from adversity and a shared sense of hardship, rather than through mutual respect and trust. These very different approaches to group solidarity can create tensions when these groups try and work together.

Whilst bonding capital was evidently high within China-based B and UKC and UKA, it was apparent that Putnam's (2000) notion of bridging capital was more problematic when these academic members discussed their inter-institutional relationships. Although Granovetter (1983) labels bridging capital as the benefits afforded by weak ties, it seems in collaborative contexts that bridging capital between inter-institutional staff members must be significantly strengthened if the provision is to prosper, survive global challenges and overcome ideological differences.

Partnership B participants Steve, Kevin, and Gary, all acknowledged the value of interventions such as "secondments", "flying-faculty visits", "mentor schemes and research collaborations" as a way of improving their inter-institutional relationships. UKA participants Ann, Keith and Louise all referred to their flying-faculty visits as a way of developing empathy with their overseas colleagues. However, China-based A and C colleagues evidenced no inter-institutional initiatives that enabled them to familiarise themselves with their UK partners, with many of the interventions executed to strengthen bridging capital between the operational teams seemingly instigated by the UK partner. Consequently, participants in partnerships A and C often described themselves as 
"distant acquaintances" who "operate in different circles" (Putnam, 2000, p. 22) with little connecting them other than an obligation to fulfil a formal partnership contract.

\section{Conclusion and Managerial Implications}

HEIs across the globe that are seeking to develop international partnerships must understand that social capital is a critical component in the development of partner relations (Dhillon, 2013). Whilst academics such as Zhuang (2009) and Heffernan and Poole (2005) refer to strategic social capital, there needs to be an awareness of the importance of operational social capital in the development of transnational collaborative programme partnerships. Heffernan, Wilkins and Mohsin Butt (2018) argue, to increase student trust and university-identification, as well as enhance the reputation of partner institutions, managers must ensure that programmes and services are delivered 'efficiently and effectively'. Information needs to be shared and communicated between staff members, thereby evidencing the competency and credibility of the institutions to stakeholders. Should this not be the case, due to poor partner relations, it is likely to have a detrimental effect on the future of the collaborative programme in operation.

Evidently, social capital can be conceived of in multiple ways, and the aforementioned perspectives evidence how the concept can differ depending on one's perspective. Nevertheless, it seems fair to argue that the conceptualisations do share similarities, with these predominately revolving around resources, networks, exchange, value and benefit. An analysis of partnership literature suggests that the most beneficial forms of social capital in forming and maintaining partnerships are the critical and the democratic strains. The rational strain, with its theme of individualism and personal gains, does not correspond with the ideas advocated by academics who study partnership.

Academics such as Paldam (2000, p.629) refer to the personal relationships between individuals operating in a partnership as "glue" further defining this "glue" as "social capital" (2000, p. 629). However, conceptualising social capital as an individual endeavour dilutes the notion of partnership glue. 'Partnership' therefore, no longer signifies mutual and collective action, but represents a breeding ground for self-gratification and self-interest that services others only through the pursuit of individual endeavours. However, findings suggest that it is perhaps partner institutions that are unwittingly forcing academic members to adopt this individualistic approach, through poor infrastructure, support and governance.

This paper recommends that institutional partners engaging in transnational collaborations consider their actions regarding their proposed infrastructures and operational initiatives, to encourage and enhance the manifestation of the critical and democratic strains and reduce the likelihood of the rational strain manifesting at the operational level. This could be achieved by observing the following recommendations and practical suggestions: 
1. Clarity: The purpose and ambition of the partnership needs to be articulated to operational academic members through a comprehensive communication strategy. HEIs should make staff aware of the value of their work and how it contributes and benefits the partnership and its stakeholders through weekly team meetings and conference calls with overseas colleagues. Communicating the purpose and ambition of the partnership encourages operational academics to continue to invest effort in the project, increasing levels of trust, connectivity and cooperation.

2. Support: Academic need to be supported by institutional infrastructure and governance, so they do not feel isolated or marginalised, forced to make decisions that support individual agendas and initiatives. Senior executives and departments like Registry and the International Office, should take both a passive and active role in assisting operational academics as and when required, with clear instructions as to when an intervention may be required. Academic members need to feel supported and respected. Failure to do so, then the more likely it is that networks will develop to suit individual rather than group objectives.

3. Resourcing: Senior management should ensure operational academic members are kept abreast of tangible and intangible resource availability, as well as the processes for accessing resources. For example, documentation should exist that explain how to request and purchase travel and accommodation, IT or technological artefacts or classroom materials for offshore arrangements. Notwithstanding how to apply for additional human resource support to support educational initiatives. Senior executives should also consider ways in which to monitor and regulate the acquisition and use of these resources by operational team members, through transparent online booking or requisition systems, so members are not disadvantaged or constrained by others in their ability to generate meaningful social interactions.

4. Networks: Senior executives at partnering institutions should consider improving connectivity through face-to-face meetings, such as conference calls, flying faculty and staff/ research exchanges. Professional development opportunities, such as skills training, teaching qualifications, memberships of professional bodies, and peer mentoring should also be encouraged, as these are likely to enhance bonding and bridging capital between operational teams that generate shared identities and reciprocity over time.

\section{Research Limitations}

The author acknowledges the limitations of this study. Findings from this paper are not considered to be generalisable, but merely illustrate the complexity of managing transnational collaborative programme partnerships operations, and the implications this has on a partnerships ability to effectively and productively deliver an educational service. However, whilst three Chinese- British collaborative joint-degree programme partnerships operating at the same Host 
institution in China, provides an unusual case with a limited sample size, it starts a conversation around the salience of offshore operational relationships.

Operational relationships underpin the educational venture, whereby the educational service, and its delivery, are clearly influenced by partner relations. Furthermore, the cases used in this study provide insights into the development of transnational educational opportunities in China and the way the Chinese policy of massification in higher education has enabled such ventures to establish (Huang, 2003; Ho Mok \& Xu, 2008). As our knowledge increases, it is hoped this study will encourage more investigations of other types of China-British transnational arrangements, so greater understandings of the mechanisms that influence operational relationships and the educational venture become apparent.

\section{References}

Adams, A. (2011). Sports development and social capital. In B. Houlihan \& M. Green (Eds.), Routledge Handbook of Sport Development (pp. 72-86). London: Routledge.

Becker, G. S. (1964). Human Capital: A Theoretical and Empirical Analysis. New York: National Bureau of Economic Research.

Billett, S., Ovens, C., Clemans, A., \& Seddon, T. (2007). Collaborative working and contested practices: forming, developing and sustaining social partnerships in education. Journal of Education Policy, 22(6), 637-656.

BIS. (2014). The Value of Transnational Education to the UK. BIS Research Paper Number 194. London: Department for Business Innovation and Skills.

Bourdieu, P. (1980). Le capital social: notes provisoires. Actes de la Recherche en Sciences Sociales, 31, 2-3.

Bourdieu, P. (2006). The forms of capital. In H. Lauder, P. Brown, J. A. Dillabough, \& A. H. Halsey (Eds.), Education, Globalisation and Social Change (pp. 105-118). Oxford: Oxford University Press.

Bourdieu, P., \& Wacquant, L. (1992). An Invitation to Reflexive Sociology. Chicago: University of Chicago Press.

Burt, R. S. (1997). A note on social capital and network content. Social Networks, 19(4), 355-373.

Coleman, J. S. (1988). Social capital in the creation of human capital. American Journal of

Sociology, 94, S95-S120.

Coleman, J. S. (1994). Foundations of Social Theory. Cambridge: Belknap Press.

Dhillon, J. K. (2013). Senior Managers' perspectives of leading and managing effective, sustainable and successful partnerships. Educational Management Administration and Leadership, 41(6), 736-750.

Dobos, K. (2011). "Serving two masters" - academics' perspectives on working at an offshore campus in Malaysia. Educational Review, 63(1), 19-35. 
Eddy, P. L. (2010). Partnerships and Collaborations in Higher Education. In K. Ward \& L. E. Wolf-Wendel (Eds.), ASHE Higher Education Report, 36 (2). San Francisco, CA: ASHE.

Field, J. (2008). Key Ideas: Social Capital. Abingdon: Routledge.

Granovetter, M. (1983). The strength of weak ties: a network theory revisited. Sociological Theory, 1, 201-233.

Gray, B. (1985). Conditions facilitating interorganizational collaboration. Human Relations, 38(10), 911-936.

Guba, E. G., \& Lincoln, Y. S. (1989). Fourth Generation Evaluation. London: Sage Publications. Heffernan, T., \& Poole, D. (2005). In search of "the vibe": Creating effective international education partnerships. Higher Education, 50(2), 223-245.

Heffernan, T., \& Poole, D. (2004). "Catch me I'm falling": key factors in the deterioration of offshore educational partnerships. Journal of Higher Education Policy and Management, 26(1), 75-90.

Heffernan, T., Wilkins, S., \& Mohsin Butt, M. (2018). Transnational Higher Education: The importance of institutional reputation, trust and student-university identification in international partnerships. International Journal of Education Management, 32(2), 227-240.

Helms, R. M. (2015). International Higher Education Partnerships: A Global Review of Standards and Practices. Washington D.C: American Council on Education (ACE).

Hoare, L. (2013). Swimming in the deep end: transnational teaching as culture learning? Higher Education Research \& Development, 32(4), 561-574.

Huang, F. (2003). Transnational higher education: a perspective from China. Higher Education Research \& Development, 22(2), 193-203.

Keay, J., May, H., \& O’ Mahony, J. (2014). Improving learning and teaching in transnational education: can communities of practice help? Journal of Education for Teaching, 40(3), 251-266. Lévi-Strauss, C. (1969). The Elementary Structures of Kinship. Boston: Beacon Press. Lin, N. (2001). Social Capital: A Theory of Social Structure and Action. Cambridge: Cambridge University Press.

Knight, J. (2004). Internationalisation remodelled: definition, approaches and rationales. Journal of Studies in International Education, 8(1), 5-31.

Knight, J. (2008). Joint and double degree programmes: Vexing questions and issues. London: The Observatory on Borderless Higher Education.

Miles, M. B., \& Huberman, A. M. (1994). An Expanded Sourcebook: Qualitative Data Analysis (2nd ed.). London: Sage Publications.

Mohr, J., \& Spekman, R. (1994). Characteristics of partnership success: partnership attributes, communication behaviour and conflict resolution techniques. Strategic Management Journal, $15(2), 135-152$. 
Mok, K. H., \& Xu, X. (2008). When China opens to the world: A study of transnational higher education in Zhejiang, China. Asia Pacific Education Review, 9(4), 393-408.

Paldam, M. (2000). Social capital: One or many? Definition and measurement. Journal of Economic Surveys, 14(5), 629-653.

Portes, A. (2000). Social capital: its origins and applications in modern sociology. In E. L. Lesser (Ed.), Knowledge and Social Capital: Foundations and Applications (pp. 43-67). Woburn:

Butterworth-Heinemann.

Putnam, R. D. (1993). Making Democracy Work: Civic Traditions in Italy. Princeton: Princeton University Press.

Putnam, R. D. (1996). Who killed civic America? Prospects, 7(24), 66-72.

Putnam, R. D. (2000). Bowling Alone: The Collapse and Revival of American Community. New York: Simon \& Schuster.

QAA. (2010). Code of Practice for the Assurance of Academic Quality and Standards in Higher Education: Collaborative Provision and Flexible and Distributed Learning (October 2010 ed.). Gloucester: QAA.

Shams, F. \& Huisman, J. (2016). The role of institutional dual embeddedness in the strategic local adaptation of international branch campuses: evidence from Malaysia and Singapore. Studies in Higher Education, 41(6), pp. 955-970.

Shore, S., \& Groen, J. (2009). After the ink dries: doing collaborative international work in higher education. Studies in Higher Education, 34(5), 533-546.

Smith, K. (2012). Exploring flying faculty teaching experiences: motivations, challenges and opportunities. Studies in Higher Education, 39(1), 117-134.

Taylor, J. (2016). Understanding international partnerships: a theoretical and practical approach. Perspective: Policy and Practice in Higher Education, 20(2-3), 44-50.

UNESCO and the Council of Europe. (2002). Code of Good Practice in the Provision of Transnational Education: Section 1. Retrieved 28th Sept, 2012, from https://www.coe.int/t/dg4/highereducation/recognition/Code\%20of\%20good\%20practice_EN.asp Zhuang, L. (2009). The challenges facing Sino-UK transnational education: an institutional experience. Journal of Knowledge-based Innovation in China, 1(3), 243-244. 